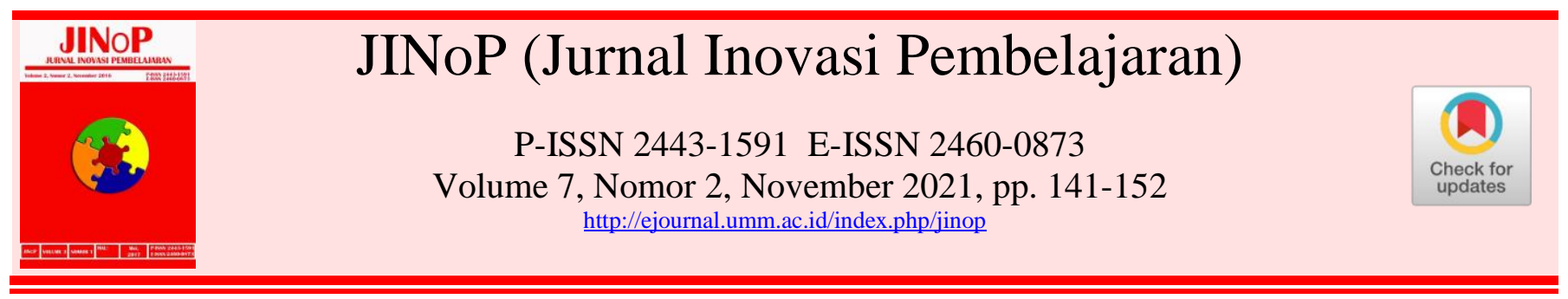

\title{
Lesson study learning community melalui model Transcript Based Learning Analysis (TBLA) dalam pembelajaran IPA
}

\author{
Eko Susetyarini $^{1)}$, Sri Wahyuni ${ }^{2)}$, Roimil Latifa ${ }^{3)}$ \\ ${ }^{1}$ Program studi Pendidikan Biologi, Fakultas Keguruan dan Ilmu Pendidikan, Universitas \\ Muhammadiyah Malang, Jl. Raya Tlogomas 246, Malang, Indonesia \\ ${ }^{2}$ Program studi Pendidikan Biologi, Fakultas Keguruan dan Ilmu Pendidikan, Universitas \\ Muhammadiyah Malang, Jl. Raya Tlogomas 246, Malang, Indonesia \\ ${ }^{3}$ Program studi Pendidikan Biologi, Fakultas Keguruan dan Ilmu Pendidikan, Universitas \\ Muhammadiyah Malang, Jl. Raya Tlogomas 246, Malang, Indonesia
}

susetyorini@umm.ac.id ; sri_wahyuni@umm.ac.id*; roimillatifa@umm.ac.id

*Penulis Koresponden

\begin{abstract}
ABSTRAK
Lesson study membangun komunitas belajar atau dikenal dengan Learning Community antar guru, peserta didik, akademisi maupun pemerhati Pendidikan saat ini banyak diteliti. Model Transcript Based Learning Analysis (TBLA) adalah salah satu model yang digunakan untuk menganalisis transkrip pembelajaran secara lebih mendalam. Penelitian ini bertujuan mendeskripsikan pola pembelajaran lesson study pada pembelajaran IPA melalui analisis TBLA. Metode yang digunakan dalam penelitian ini adalah metode penelitian kualitatif diskriptif untuk menggambarkan fenomena-fenomena yang berlangsung secara apa adanya. Penelitian dilakukan pada pembelajaran kelas VIII SMP Muhammadiyah 8 Kota Batu, materi jaringan tumbuhan, dengan siklus plan, do, see. Instrumen penelitian ini berupa video dan audio recorder serta lembar catatan lapangan peneliti. Pengumpulan data dilakukan melalui 3 cara yaitu dokumentasi, observasi dan diskusi. Data yang dikumpulkan pada penelitian ini berupa transkrip pembelajaran Lesson study Learning Community.Tehnik analisis data menggunakan model analisis TBLA. Hasil penelitian memaparkan percakapan yang terjadi antara guru dan peserta didik, terdapat 43 percakapan guru-siswa, pembelajaran berpola linier, kategori mengarah ke Student Center Learning. Simpulan Penelitian ini adalah Pembelajaran IPA materi jaringan tumbuhan berpola linier yang menggambarkan pembelajaran semakin menguat untuk mencapai tujuan pembelajaran dan Kategori SCL yang berpusat pada siswa. Saran penelitian ini dapat digunakan sebagai acuan refleksi dalam mengembangkan profesionalitas guru untuk membentuk pembelajaran yang lebih efektif.
\end{abstract}

Kata Kunci: Lesson Study Learning Community; pola pembelajaran; model TBLA; pembelajaran IPA.

\section{ABSTRACT}

Lesson study builds a learning community among teachers, students, academics and education observers. Transcript Based Learning Analysis (TBLA) model is one of the models used to analyze learning transcripts in more depth. This study aims to describe the learning patterns in lesson study on science learning through TBLA analysis. The method in this research is descriptive qualitative research to describe the phenomena that take place as they are. The research was conducted in class VIII SMP Muhammadiyah 8 Batu City, plant tissue material, with cycle plan, do, see. The research instruments were in the form of video and audio recorders as well as researcher's field notes sheets. Data collection was carried out through 3 ways, documentation, observation and discussion. The data collected in this study were in the form of learning transcripts from the Lesson Study Learning Community. Techniques using data using the Transcript Based Learning Analysis (TBLA) model of research results describe the conversations 
that occur between teachers and students, there are 43 teacher-student conversations, linear patterned learning, categories leading to the Student Center Learning. The conclusion of this research Were the natural science learning, plant tissue material with a linear pattern which describes increased learning to achieve learning objectives and student-centered SCL categories. The results of this study can be used as a reference for reflection in developing teacher professionalism to form more effective learning.

Keywords: Lesson Study Learning Community; learning patterns; TBLA model; science learning.

diunggah: 2021/01/03, direvisi: 2021/11/08, diterima: 2021/11/27, dipublikasi:2021/11/30

Copyright (c) 2021 Susetyorini et al

This is an open access article under the CC-BY license

Cara sitasi: Susetyarini, E., Wahyuni, S., \& Latifa, R. (2021). Lesson study learning community melalui model transcript based learning analysis (TBLA) dalam pembelajaran IPA. JINoP (Jurnal Inovasi Pembelajaran), 7(2). https://doi.org/10.22219/jinop.v7i2.15083

\section{PENDAHULUAN}

Pembelajaran merupakan proses interaksi antara pengajar, siswa, dan media pembelajaran dengan adanya interaksi tersebut, siswa dapat secara aktif mengembangkan keterampilan dan pola pikir dalam belajar. Pembelajaran berlangsung secara interaktif, inspiratif, menyenangkan, menantang, serta dapat memotivasi siswa dalam mencapai kompetensi yang diharapkan (Susilo, H, Chotimah, H, Ridwan J, Jumiati, Yuyun D.S, 2009; Susetyarini, E; Rofieq, A.N, Latifa, 2018). Keberhasilan pembelajaran bukan ditentukan oleh nilai atau hasil akhir peserta didik, tetapi proses saat pembelajaran berlangsung siswa nyaman, senang, dan mempunyai 4 karakter (kolaboratif, komunikatif, kritis dan kreatif), (Barry, 2012;Frydenberg, M., \& Andone, 2011;Boholano, H, 2017, (Binkley, 2012). Pembelajaran yang menyenangkan, inovatif dan menantang merupakan pembelajaran yang mengarah ke sekolah model abad 21. Sekolah modern dibentuk berdasarkan prinsip dasar pencapaian simultan antara kualitas (quality) dan kesetaraan (equality) (Sato, 2014).

Kualitas dan inovasi pembelajaran merupakan hal yang mutlak ada dalam pembelajaran, salah satu cara untuk meningkatkan keduanya adalah dengan menyelenggarakan pembelajaran melalui kegiatan lesson study (Setiawan, A. Mujianto, G. Asihono, 2020, Rahayu \& Miswadi, 2012) Peningkatan kualitas pembelajaran di sekolah dipengaruhi banyak faktor. Faktor tersebut bisa dilihat dari: pendidik (guru), peserta didik, sarana dan prasarana, lingkungan, dan manajemennya (Mutiani. Warmansyah, M. Abbas Syaharuddin. Susanto, 2020) Lesson Study memiliki prinsip dasar yakni peningkatan kualitas pembelajaran dinilai bertahap dengan belajar dari pengalaman sendiri dan orang lain dalam melakukan kegiatan pembelajaran. Lesson Study untuk pengembangan profesi guru menekankan pada kemampuan guru untuk mengevaluasi, berdisikusi dan belajar dari praktek mengajar yang telah dilakukan (Hajar, 2019 ; Marten, D \& ClercGeorgy, 2015, Hendayana, 2006) Lesson Study sebagai satu proses tidak hanya melibatkan guru sebagai aktor utama pembelajaran. Namun melibatkan peran observer (guru lain/mitra, ahli pendidikan dosen dan pihak-pihak lain terkait) dalam pembelajaran sebagai pengamat jalannya aktivitas belajar. Pengamatan ini dimaksudkan agar terjadi refleksi pembelajaran sehingga memungkinkan terjadinya perubahan khususnya peningkatan komunitas belajar (Mutiani. dkk, 2020; Supriatna, 2018). Seiring berjalannya waktu (Sato, 2012) mengembangkan Lesson Study dalam rangka membangun komunitas belajar itu lebih dikenal dengan 
Lesson Study Learning Community atau lebih dikenal dengan LS-LC (Hajar \& Hendayana, 2018).

LS-LC memandang kelas dan sekolah sebagai lingkungan belajar, yang memandang setiap anggotanya perlu saling belajar, saling peduli, saling belajar dan saling terlibat dalam reformasi sekolah. Fokus LS-LC adalah dialog pembelajaran yang dibentuk untuk meningkatkan kualitas pembelajaran. Pembentukan komunitas belajar yang memungkinkan hubungan saling belajar dan saling mendengarkan dalam dialog pembelajaran menjadi dasar dalam mendesain pembelajaran, observasi, refleksi serta me re-design pembelajaran bersama-sama dalam LS-LC (Sato, 2012).

Hasil observasi awal di SMPM 8 kota Batu, LS-LC yang sudah berlangsung dua tahun terakhir, waktu diskusi antar guru terbatas, bila berdiskusi tentang pelaksanaan pembelajar seperti diselidiki oleh rekannya, antar guru sungkan untuk berbicara, saat refleksi biasanya hasil observasi tetapi bukan data objektif tentang bagaimana siswa belajar, hasil refleksi ini belum digunakan secara maksimal untuk perbaikan pembelajaran berikutnya (Susetyarini, E; Rofieq, A.N, Latifa, 2018, Susetyarini et al, 2019), maka perlu penajaman lensa belajar pada saat pelaksanaan LS-LC. Setiap guru pada satuan pendidikan berkewajiban mengembangkan pembelajaran berlangsung secara interaktif, inspiratif, menyenangkan, menantang, memotivasi peserta didik untuk berpartisipasi aktif, serta memberikan ruang yang cukup bagi prakarsa, kreativitas, dan kemandirian sesuai dengan bakat, minat, dan perkembangan fisik serta psikologis siswa, karakteristik siswa. Oleh karena itu guru harus sangat detail merancang lesson design (Kemendikbud, 2019).

Hasil evaluasi LS-LC tahun 2019 antara guru, kepala sekolah dan Pembina dari UMM, maka muncul permasalahan yang sangat penting dari pengalaman pelaksanaan Lesson study tahun yang lalu, yaitu guru perlu merubah perilaku untuk berdiskusi antar guru, menajamkan lensa belajar pada saat open class, dengan menekankan pada karakter kolaborasi, komunikasi, keatif dan kritis. Hal tersebut belum terekam secara tajam tentang bagaimana guru belajar, bagaimana siswa belajar yang bermanfaat untuk perbaikan pembelajaran selanjutnya. Kebijakan pemerintah pada masa pandemi Covid 19 mengapresiasi langkah proaktif yang dilakukan pemerintahan dalam menerapkan metode belajar online atau dalam jaringan (daring), mendorong pembelajaran secara daring untuk para siswa. Adanya wabah Covid-19 pembelajaran daring menjadi salah satu jalan keluar yang harus dilakukan untuk pembelajaran tetap berlangsung. Program pembelajaran daring pada dasarnya dapat menumbuhkan sifat kemandirian belajar peserta didik (Dewi, 2017), maka diperlukan peningkatan minat belajar berbasis LS-LC pada masa pandemic covid 19, bagaimana open plan, bagaimana open class dan refleksi di SMP Muhammadiyah 8 Batu.

Penelitian sebelumnya yang mengungkap profil dialog yang terbentuk pada pembelajaran dalam upaya membentuk komunitas belajar LS-LC masih sangat jarang dilakukan. Penelitian terkait Transcript Based Learning analysis (TBLA) pernah dilakukan oleh Hajar (2019), Mutiani et al (2020), Rahayu (2019), Amintarti et al (2020). Namun penelitian terkait analisis pembelajaran TBLA, pola pembelajaran materi jaringan tumbuhan belum pernah dilakukan.

SMP Muhammadiyah 8 Kota Batu adalah salah satu SMP yang bersemangat untuk meningkatkan kualitas pendidikan melalui LS-LC. Ironisnya pembelajaran di SMP masih banyak mengabaikan hak belajar siswa. Sebagian besar guru kurang tajam (15\%-16\%) dari sekitar 5-6 observer dalam mengamati bagaimana siswa belajar (lensa belajar), memberikan kesempatan siswa untuk melakukan 
pembelajaran aktif. Pembelajaran seringkali tertutup dari pengamatan orang lain dan guru sangat mendominasi kelas. Belum maksimalnya guru dalam membicarakan rencana pembelajaran yang akan dilakukan dengan rekan guru, tidak pernah dilakukan refleksi untuk menguatkan praktik baik yang timbul pada saat pembelajaran dan tidak pernah dilakukan follow up untuk temuan praktek baik pembelajaran yang didapatkan Itulah keadaan dan fakta pembelajarannya setelah 2 tahun diimplementasikan Lesson Study, oleh karena itu perlu membelajarkan/melatih guru dalam penajaman lensa belajar tentang kolaborasi, komunikasi, kritis dan kreatif, hal ini dirasakan mendesak dan penting untuk segera diwujudkan dalam masa pandemi Covid 19.

Penelitian ini bertujuan untuk mendeskripsikan pola pembelajaran lesson study pada pembelajaran IPA melalui analisis TBLA pada pembelajaran IPA materi jaringan tumbuhan. Hasil penelitian ini akan dijadikan sebagai acuan refleksi dalam mengembangkan profesionalitas guru untuk membentuk pembelajaran yang lebih efektif.

\section{METODE}

Metode penelitian yang digunakan dalam penelitian ini adalah penelitian kualitatif diskriptif. Metode Penelitian ini dipilih karena merupakan salah satu metode penelitian untuk menggambarkan secara sistematis fakta dan karakteristik subyek atau obyek yang diteliti secara tepat (Cresswell, 2013). Metode penelitian kualitatif sering disebut metode penelitian naturalistik karena penelitiannya dilakukan pada kondisi yang alamiah (natural setting). Penelitian dilakukan pada objek yang alamiah yang berkembang apa adanya, tidak dimanipulasi oleh peneliti dan kehadiran peneliti tidak begitu mempengaruhi dinamika pada objek tersebut (Sugiyono, 2015). Penekanan metode penelitian kualitatif terletak pada pengungkapan suatu fenomena secara apa adanya (Cresswell, 2013). Selain itu ditambahkan oleh Fraenkel, J. R., Wallen, N. E., \& Hyun (2011), bahwa metode kualitatif lebih menekankan pada sifat alamiah dari fenomena-fenomena secara lebih rinci. Penelitian kualitatif deskriptif dimaksudkan untuk memperoleh gambaran tentang fenomena-fenomena yang berlangsung atau dapat juga mendeskripsikan suatu keadaan berikut dengan perkembangannya (Arifin, 2011).

Secara garis besar alur penelitian yang dilakukan dibagi menjadi tiga tahapan, yaitu sebagai berikut:

a. Tahap Persiapan.

1. Persiapan Studi kepustakaan tentang mengenai materi pembelajaran IPA

2. Persiapan alat (handycam dan audio recorder) untuk merekam gambar dan suara seluruh aktivitas pada kegiatan Lesson Study.

3. Persiapan instrumen penelitian untuk menganalisis pola pembelajaran menggunakan Transcript Based Lesson Analysis

b. Tahap Pelaksanaan.

Pelaksanaan kegiatan Lesson Study terdiri dari 3 tahapan yaitu plan (desain), do (observasi) dan see (refleksi) pembelajaran

1. Pembuatan Chapter design dan Lesson Design (plan) pada tahap plan, guru melakukan perencanaan pembelajaran yang akan dilakukan dalam pembelajaran. Perencanaan pembelajaran melibatkan 5 orang guru IPA, 2 orang mahasiswa dan dosen sebagai ahli

2. Pada tahap pelaksanaan pembelajaran $(d o)$, peneliti menggunakan instrumen lembar observasi untuk mengamati pembelajaran IPA di kelas. Pengamatan selama proses pembelajaran dibantu oleh observer lain untuk memperkuat 
hasil pengamatan yang dilakukan. Keseluruhan kegiatan pada tahap pelaksanaan penelitian direkam secara audio dan video yang kemudian data rekaman akan ditranskrip ke dalam bentuk verbal untuk dilakukan analisis.

3. Kemudian dilakukan tahap see sebagai refleksi guru untuk memperbaiki pembelajaran selanjutnya.

\section{c. Tahap Penyelesaian}

Pada tahap ini dilakukan pengumpulan data penelitian, transkrip desain, observasi, refleksi, analisis data penelitian.

Penelitian ini melibatkan siswa kelas VIII SMP Muhammadiyah 8 Kota Batu Jawa Timur. Sekolah tersebut dipilih, karena telah lama mengikuti kegiatan Lesson Study dan terbiasa melakukan tahapan-tahapan dalam aktivitas Lesson Study. Partisipan dalam penelitian ini adalah siswa SMP Muhammadiyah 8 yang berjumlah 20 orang, 5 orang guru IPA termasuk kepala sekolah, 4 Dosen dan 2 mahasiswa. Penelitian dilakukan pada semester ganjil 2020/2021.

Teknik pengumpulan data yang digunakan pada penelitian kualitatif ini yaitu dengan triangulasi. Menurut Fraenkel et.al, (2011) triangulasi merupakan teknik pengumpulan data yang bersifat menggabungkan berbagai teknik pengumpulan data dan sumber yang ada. Tahapan pengumpulan data yang dilakukan yaitu sesuai dengan tahap Lesson Study (desain, observasi, refleksi) selama dua siklus pembelajaran. Pengumpulan data pada penelitian ini menggunakan 3 metode, melalui dokumentasi, (Video, rekaman suara guru, siswa), Observasi (Catatan lapang pada waktu plan, do, see), diskusi (rekaman suara, video).

Teknik analisis data menggunakan Model analisis pembelajaran Transcript Based Learning Analysis (TBLA). Analisis pola pembelajaran yang dilakukan akan difokuskan pada tahap pelaksanaan pembelajaran (do), karena penelitian ini dimaksudkan untuk memperoleh gambaran pola pembelajaran (Learning Patterns) terjadi pada pembelajaran IPA di kelas 8, SMP Muhammadiyah Batu, pada materi struktur anatomi tumbuhan. Penentuan Pola Pembelajaran mengikuti prosedur (Hidayat, A. Hendayana, S. 2020).

Pola umum yang terjadi pada sampel-sampel pembelajaran adalah sebagai berikut:

1. Pola A (Pola Linier). Semua tahapan pembelajaran saling sambung dan saling menguatkan untuk mencapai tujuan belajar yang diinginkan.

2. Pola B. Pembelajaran yang awalnya linear menguat untuk mencapai tujuan yang diinginkan, namun di tengah-tengah (bagian tertentu dalam pembelajaran itu), kelas tiba-tiba berbelok pada topik yang tidak nyambung/ tidak sesuai dengan tujuan pembelajaran, namun akhirnya pembelajaran Kembali ke lagi ke Jalur Utama, yaitu tujuan pembelajaran yang ingin di capai

3. Pola C. Pembelajaran yang sepertinya ada bagian yang tidak berhubungan dengan tujuan pembelajaran muncul di tengah-tengah (salah satu segmen pembelajaran), namun akhirnya berhubungan langsung dengan tujuan ketika memasuki akhir pembelajaran

4. Pola D. Pembelajaran yang arah nya terbagi menjadi dua (atau mungkin lebih), sehingga tujuan pembelajaran terbagi dua, dan antara kedua tujuan ini tidak saling berhubungan.

5. Pola E. Pembelajaran yang tujuan pembelajaran nya terputus di tengah jalan, kemudian membuat lagi awal yang baru untuk tujuan yang sama atau untuk tujuan pembelajaran yang berbeda, yang baru. 
6. Pola F. Pembelajaran yang benar-benar polanya saling terpisah satu sama lain, tidak tidak tahu kemana arah nya serta pencapaian tujuan pembelajaran yang diinginkan.

7. Pola G. Pembelajaran yang tidak mencapai tujuan yang diinginkan karena keterbatasan Waktu, namun berakhir kelas selesai dengan variasi Pola A-B-CD-E bahkan $F$ diatas. Ada peluang pembelajaran selanjutnya tujuan pembelajaran akan dicapai.

Kategorisasi Transcript dialog guru dan siswa dalam pembelajaran dikelompokkan menjadi 3 yaitu: Dialog minimalis, Dialog kendali guru, dan dialog kendali kelas. Dialog minimalis terdiri dari DM1 dan DM2. DM1: Guru menjelaskan/bertanya, tidak ada respon verbal, mungkin ada respon gesture/fisik dari siswa; DM2: Guru menjelaskan siswa merespon tetapi menggumam/inaudible, Dialog Kendali Guru terdiri dari DG1 dan DG2. DG1: Guru bertanya-siswa menjawab dengan jawaban sejenis ya/tidak/melengkapi potongan kata; DG2: Guru bertanya-siswa menjawab dengan membaca teks. Dialog Kendali Kelas terdiri dari DK1 sampai DK7. (DK1: Guru bertanya-siswa menjawab dengan mengingat/recall, termasuk siswa diminta membacakan sesuatu di kelas; DK2:siswa bertanya ke Guru, Guru langsung menjawab di kelas; DK3:Guru bertanya siswa menjawab dengan reasoning/argument/alasannya tanpa melihat buku/teks; DK4: siswa bertanya ke Guru, Guru tidak menjawab/meneruskan pertanyaan ke kelas baik mendapat/tidak mendapat jawaban; DK5:siswa bertanya ke siswa lain/berdiskusi sesame siswa selama kelompok dengan dipandu guru; DK6:siswa dalam kerja kelompok bertanya ke Guru, Guru menjawab/berdiskusi dengan kelompok itu; DK7: siswa bertanya ke siswa lain/berdiskusi sesama siswa selama kerja kelompok tanpa dipandu/kehadiran guru (Hidayat, 2020).

\section{HASIL DAN PEMBAHASAN}

Hasil penelitian terkait pelaksanaan LS-LC berupa Pola pembelajaran (Learning Pattern) pada pembelajaran IPA kelas 8 SMP Muhammadiyah 8 Kota Batu materi struktur anatomi tumbuhan ditunjukkan pada Gambar 1, Gambar 2 di bawah ini:

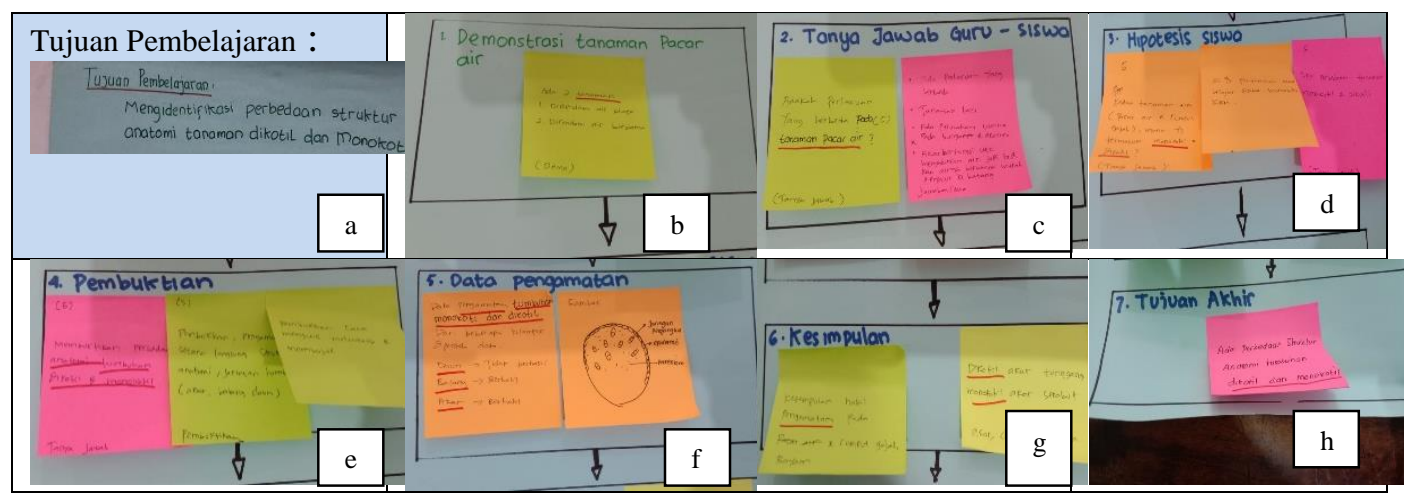

Gambar 1. Tahapan pelaksanaan pembelajaran

Analisis pola pembelajaran yang dilakukan difokuskan pada tahap pelaksanaan pembelajaran (do). Gambar 1a menunjukkan tujuan pembelajaran yaitu mengidentifikasi perbedaan struktur anatomi tanaman dikotil dan monokotil. Gambar 1b menunjukkan tahapan langkah pembelajaran ke 1 yaitu guru melakukan demonstrasi tanaman pacar air dengan menunjukkan 2 tanaman yang direndam air biasa dan direndam air berwarna, Gambar 1c menunjukkan langkah pembelajaran 
ke 2 yaitu kegiatan tanya jawab antara guru dan siswa. Guru bertanya" adakah perlakuan yang berbeda pada tanaman pacar air?". Jawaban siswa ada perlakuan yang berbeda, tanaman layu, ada perubahan warna bunga dan akar. Akar berfungsi menyalurkan air jadi air berwarna merah, kemudian disalurkan ke batang. Gambar 1d menunjukkan langkah pembelajaran ke 3 yaitu kegiatan siswa melakukan hipotesis "Dari kedua tanaman mana yang termasuk dikotil dan monokotil, apa perbedaan tanaman monokotil dan dikotil?", Siswa berfikir beberapa siswa menjawab benar dengan melihat ciri morfologisnya. Gambar 1e menunjukkan langkah pembelajaran ke 4 yaitu pembuktian. Siswa membuktikan perbedaan anatomi tumbuhan monokotil dan dikotil melalui eksperimen, siswa mengadakan pengamatan secara langsung struktur anatomi akar, batang, daun dengan mengiris secara melintang dan membujur, Gambar 1f menunjukkan langkah pembelajaran ke 5 yaitu pengamatan data hasil praktikum. Sebagian siswa gagal dalam membuat prepat daun, beberapa mahasiswa berhasil membuat preparat akar dan batang. Gambar 1g menunjukkan langkah pembelajaran ke 6 yaitu pengambilan kesimpulan, tanaman monokotil akar serabut, dan tanaman dikotil akar tunggang. membuat tanaman Gambar 1h menunjukkan langkah pembelajaran ke 7 yaitu mengetahui tujuan akhir terdapat perbedaan struktur anatomi tumbuhan dikotil dan monokotil.

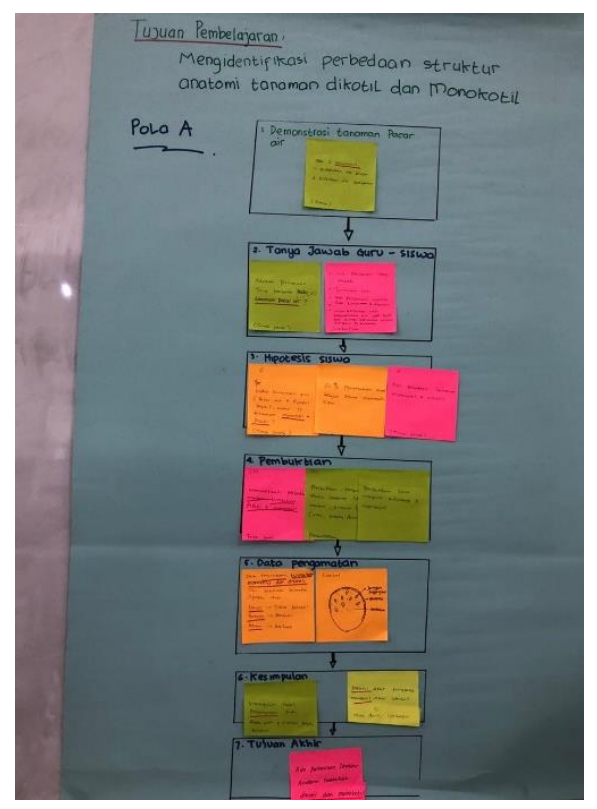

Gambar 2. Pola pembelajaran

Gambar 2 menunjukkan pola pembelajaran yang dilakukan guru dalam pembelajaran IPA materi struktur anatomi tumbuhan yang dianalisis melalui langkah-langkah pembelajaran yang meliputi 7 langkah yaitu tahap 1: demonstrasi tanaman pacar air, tahap 2: tanya jawab guru-siswa, tahap 3: hipotesis siswa, tahap 4: pembuktian, tahap 5: data pengamatan, tahap 6: kesimpulan, tahap 7: tujuan akhir. Dari tahapan -tahapan tersebut maka diperoleh gambaran pola pembelajaran yang termasuk pola A (Pola Linier) karena semua tahapan pembelajaran saling sambung dan saling menguatkan untuk mencapai tujuan belajar yang diinginkan (Hidayat, 2020).

Dari sisi proses langkah yang dirancang maupun dilaksanakan guru mengikuti pola linier, untuk mencapai tujuan pembelajaran melalui praktikum. Dari 
sisi Produk, siswa telah memperoleh ketrampilan membuat irisan melintang membujur, sikap ilmiah rasa ingin tahu, aktifitas dan semangat belajar siswa, sudah diperoleh siswa, namun demikian dari sisi pemahaman pengetahuan maupun produk akhir sesuai tujuan pembelajaran belum tercapai. Siswa berhasil membuat dan mengamati preparat struktur anatomi batang monokotil, dan menemukan berkas pembuluh pengangkut yang tersebar. Namun untuk jaringan membuat preparat daun dikotil dan monokotil belum berhasil. Melalui transkrip dialog guru dan siswa belum ada informasi mengenai keberhasilan membuat dan mengamati anatomi akar. Sehingga melalui praktikum tersebut siswa belum bisa menemukan perbedaan anatomi tumbuhan daun, akar dan batang dikotil dan monokotil. Dari transkrip dialog di akhir percakapan siswa sudah bisa membedakan tanaman dikotil dan monokotil secara morfologi yang merupakan bekal atau modal awal untuk mempelajari perbedaan struktur anatomi tumbuhan dikotil maupun monokotil. Agar bisa memahami materi dengan baik dibutuhkan pengetahuan awal yang lebih baik, terkait perbedaan struktur anatomi tumbuhan dikotil dan monokotil. Melalui kegiatan Praktikum dapat meningkatkan kemampuan berfikir kritis siswa (Wahyuni et al, 2019; Wahyuni, 2019).

Pembelajaran materi jaringan perlu didukung dengan praktikum karena siswa dihadapkan dengan bermacam-macam jaringan yang tidak dapat diamati tanpa bantuan mikroskop (Triani et al, 2018). Agar dapat mencapai tujuan pembelajaran maka praktikum harus dirancang dan dikelola dengan baik. Guru sebagai pendidik harus terus menerus mengembangkan kualitas pembelajaran agar segala kesulitan dalam pembelajaran dapat dipecahkan dengan tetap mengacu pada tujuan semula yaitu meningkatkan prestasi siswa (Ulfah, 2012). Guru perlu memperbaiki hasil dengan penerapan suatu tindakan yang mampu mengubah hasil belajar ke arah yang lebih baik.

Tabel 1. Contoh Tampilan Transkrip Dialog Pembelajaran IPA

Sekolah : SMP Muhammadiyah 8 Batu

Mata pelajaran : IPA

Materi : Struktur Anatomi Tumbuhan (siklus II),

Waktu : 40 menit x 2 jp

Kelas : VIII-B

\begin{tabular}{|c|c|c|c|c|c|}
\hline \multicolumn{2}{|c|}{ Waktu } & \multirow{2}{*}{$\begin{array}{c}\text { Pembicara } \\
\text { G/S }\end{array}$} & \multirow[b]{2}{*}{ Index } & Ucapan & \multirow[b]{2}{*}{ Situasi } \\
\hline menit & detik & & & Guru/siswa & \\
\hline 2 & 15 & $\mathrm{G}$ & 1 & $\begin{array}{l}\text { Oke anak-anak perhatikan } \\
\text { didepan bu Cantia membawa } 2 \\
\text { tanaman kira-kira ada yang tau } \\
\text { ini tanaman apa? }\end{array}$ & \\
\hline & & & & & $\begin{array}{l}\text { guru menunjukkan } \\
\text { tanaman yang } \\
\text { dibawanya }\end{array}$ \\
\hline 2 & 30 & Ss & 2 & Pacar air, anggrek & \\
\hline 2 & 56 & $\mathrm{G}$ & 3 & $\begin{array}{l}\text { adakah perlakuan yang berbeda } \\
\text { yang saya berikan kepada } \\
\text { kedua tanaman ini? }\end{array}$ & \\
\hline 3 & 1 & Ss & 4 & $\begin{array}{l}\text { Ada, satu diberi air satu diberi } \\
\text { air juga tapi warnanya merah }\end{array}$ & \\
\hline
\end{tabular}

Keterangan:

$\mathrm{G}=$ guru, $\mathrm{S}=$ siswa, Ss siswa-siswa

148

Lesson study learning community .. 
Kegiatan LS dalam pembelajaran, selain sebagai upaya mengaktifkan siswa berdampak pada guru dapat melakukan review terhadap kinerja guru dan pengembangan kemampuan akademik dan berpikir kritis siswa serta menumbuhkan sikap berhati-hati dan bertanggung jawab dalam belajar. LS akan diobservasi dan direfleksi bersama-sama oleh observer dan guru model (Mutiani et al, 2020; Wahyuni et al, 2015; Wahyuni et al, 2019).

Tabel 1 memuat contoh tampilan transkrip dialog verbal antara guru dan siswa dalam pembelajaran IPA. Transkrip yang diperoleh kemudian dianalisis pola konstruksi pengetahuan siswa yang terjadi dalam pembelajaran IPA menggunakan metode Transcript Based Lesson Analysis (TBLA). Untuk memahami karakteristik pengaturan pembelajaran dalam waktu satu jam pelajaran, peneliti membagi pembelajaran menjadi beberapa segmen untuk dianalisis (Sarkar, 2017). Dengan membagi pembelajaran menjadi beberapa segmen, para partisipan dapat melakukan analisis pembelajaran lebih rinci, mampu mengungkapkan motivasi apa yang harus dilakukan guru untuk mendorong proses pembelajaran atau untuk melihat seberapa aktif siswa terlibat dalam pembelajaran. Menurut Elliott (2016); Arani et al (2014) menetapkan beberapa titik fokus sebagai landasan analisis yang mengacu pada berbagai perspektif analitis dan kategori pembelajaran. Peneliti kemudian melakukan analisis yang mendetail dan meta-analisis berbagai pengaturan dalam proses pembelajaran dari pembelajaran berdasarkan perspektif analitis. Analisis terhadap transkrip pembelajaran difokuskan pada dialog siswa dalam pembelajaran yang kemudian diklasifikasikan berdasarkan tipe respon sebagai fungsi komunikatif (Arvaja, 2007) yang mewakili konstruksi pengetahuan siswa.

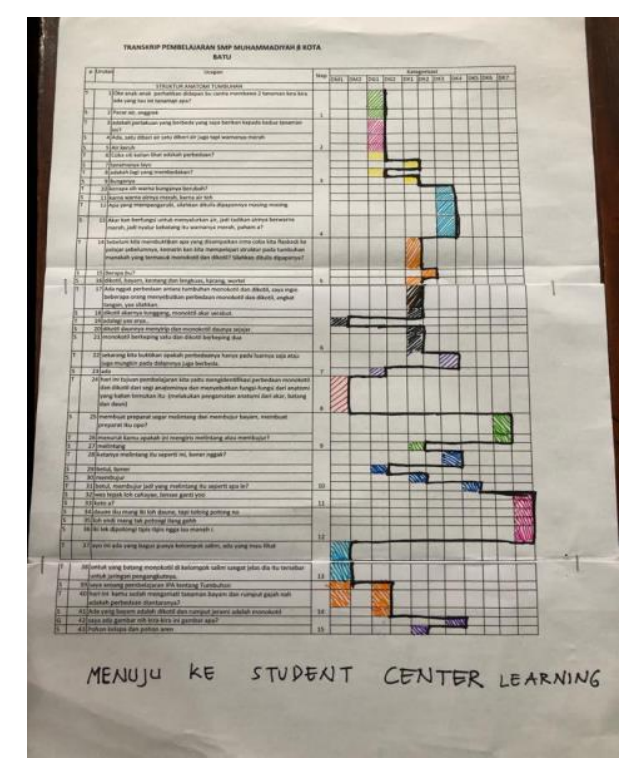

Gambar 3a

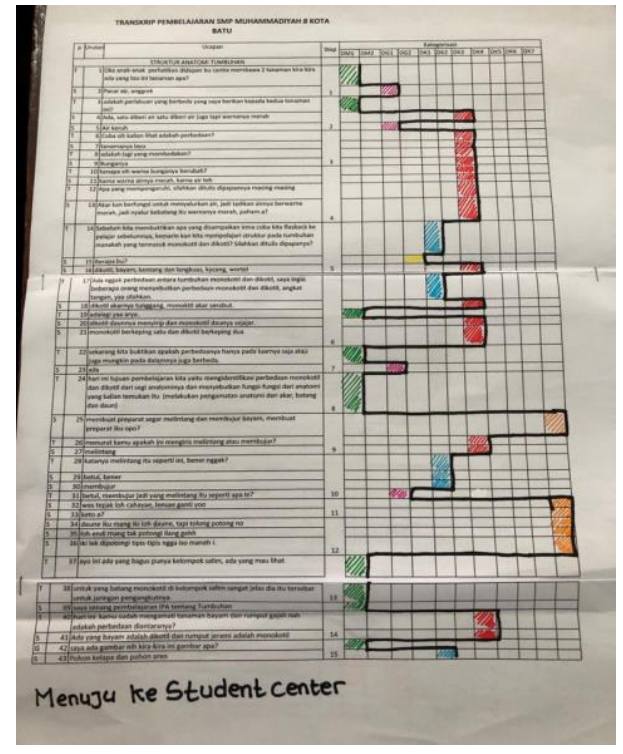

Gambar 3b

Gambar 3. Analisis TBLA ( Kategorisasi transcript dialog pembelajaran)

Gambar 3a dan 3b menunjukkan transkrip dialog percakapan sebanyak 43 ucapan. Merujuk pada Hidayat (2020), kategori transkrip dialog guru dan siswa dalam pembelajaran dikelompokkan menjadi dialog minimalis (DM), dialog kendali guru (DG), dan dialog kendali kelas (DK). Melihat aliran respon siswa sebagaimana tersaji pada gambar 3a (hasil kerja kelompok 1) dan 3b (hasil kerja kelompok 2) di atas, pada awal pembelajaran Langkah pembelajaran 1 sampai 2 (Demontrasi, tanya-jawab maka transkrip dialog guru dan siswa masuk kategori 
Dialog minimalis (DM1) dimana guru menjelaskan/bertanya, tidak ada respon verbal, mungkin ada respon gesture/fisik dari siswa (Gambar 3a), atau DG1 guru bertanya-siswa menjawab dengan jawaban sejenis ya/tidak/melengkapi potongan kata (gambar 3b). Pada langkah pembelajaran ke 3 (hipotesis) maka aliran respon siswa mulai berubah menuju ke Dialog kendali kelas (DK) kategori DK3 dimana DK3: Guru bertanya siswa menjawab dengan reasoning/argumen/alasannya tanpa melihat buku/teks; Dalam hal ini pendapat kedua kelompok hampir sama (Gambar 3a dan 3b). Pada langkah pembelajaran ke 4 (Pembuktian) dank e 5 (pengamatan) pada awal kegiatan, guru menerangkan, sehingga respon siswa kembali ke dialog minimalis kategori DM1, namun selanjutnya berubah menjadi Dialog kendali kelas Kategori DK6 dimana siswa dalam kerja kelompok bertanya ke Guru, Guru menjawab/berdiskusi dengan kelompok itu (gambar 3a) atau kategori DK7:siswa bertanya ke siswa lain/berdiskusi sesama siswa selama kerja kelompok tanpa dipandu/kehadiran guru (gambar 3b), Selama kegiatan pembuktian dan pengamatan dengan praktikum, terjadi beberapa dialog dalam kategori DK, sesekali ada variasi kategori DG. Pada tahap ke 6 kesimpulan nampak belum tuntas karena pada akhir dialog yang tertulis sebenarnya belum sampai pada kesimpulan kelas begitu juga pada tahap tujuan akhir penutupan dan tindak lanjut dialog tidak terekam. Hal ini mungkin disebabkan karena waktu sudah habis, kegiatan praktikum membutuhkan waktu yang lama sehingga pengelolaan waktu harus lebih diperhatikan. Walaupun percakapan guru murid belum selesai di akhir pembelajaran, namun sudah menggambarkan kategorisasi transcript dialog pembelajaran.

Jika dirunut dari awal sampai akhir aliran respon siswa pada transkrip dialog percakapan pembelajaran IPA materi struktur anatomi tumbuhan mengarah ke student center learning. Siswa terlibat aktif selama proses pembelajaran sejak awal pembelajaran terutama dalam kegiatan praktikum, diskusi kelompok maupun sesi tjanya jawab. Diskusi kelompok antar siswa, menjawab pertanyaan guru dalam proses pembelajaran melatih kemampuan komunikasi dan kolaborasi siswa.

Sementara itu kegiatan praktikum belajar mengiris melintang membujur, akan melatih kreatifitas siswa, sedangkan kegiatan berfikir kritis muncul pada langkah kegiatan ke 3, membuat hipotesis, kegiatan ke 4 yaitu pembuktian melalui kegiatan praktikum dan diskusi kelompok maupun kegiatan menyimpulkan untuk menyampai tujuan akhir yang diharapkan yaitu mencari perbedaan antara struktur anatomi tanaman dikotil dan monokotil. Melalui kegiatan LS-LC dengan model Analisis TBLA ini akan mempertajam kemampuan dan ketrampilan 4C (communication, collaboration, critical thinking dan creativity) siswa yang merupakan ketrampilan yang dibutuhkan pada abad 21. Melalui analisis mendalam terhadap transkrip pembelajaran dapat digunakan guru untuk merefleksi pembelajarannya guna pengembangan profesionalisme guru secara berkelanjutan (Supriatna, 2018, Hajar, 2019, Rahayu, 2019).

\section{SIMPULAN}

Pola pembelajaran (learning pattern) pembelajaran IPA melalui LS-LC dengan analisis TBLA menggambarkan pola A (pola linier) yang menggambarkan pembelajaran semakin menguat untuk mencapai tujuan pembelajaran, Kategori pembelajaran mengarah kepada pembelajaran yang berpusat pada siswa (SCL) yang berpusat pada siswa, dengan aliran respon siswa yang dominan pada DK atau diskusi kendali kelas dan sebagian DG (diskusi kendali guru) dan sebagian kecil DM (Dialog minimalis). Hasil penelitian ini dapat digunakan sebagai acuan refleksi 
dalam mengembangkan profesionalitas guru untuk membentuk pembelajaran yang lebih efektif.

\section{DAFTAR PUSTAKA}

Arani, M. R. S., Shibata, Y., Christine Lee, K. E., Kuno, H., Matoba, M., Lay Lean, F., \& Yeo, J. (2014). Reorienting the cultural script of teaching: cross cultural analysis of a science lesson. International Journal for Lesson and Learning Studies, 3(3), 215-235.

Arifin, Z. (2011). Konsep dan model pengembangan kurikulum. PT Remaja Rosdakarya.

Arvaja, M. (2007). Contextual perspective in analysing collaborative knowledge construction of two small groups in web-based discussion. International Journal of Computer-Supported Collaborative Learning, 2(2-3), 33-158.

Boholano, H. (2017). Smart social networking: 21 st century teaching and learning skills. Research in Pedagogy, 7(1), 21-29. https://doi.org/10.17810/2015.45

Barry, M. (2012). What skills will you need to succeed in the future? Phoenix Forward. AZ University of phoenix.

Binkley. (2012). Defining twenty-first century skills" dalam Assessment and Teaching of 21 st Century Skills. Springer.

Cresswell, J. (2013). Research Design: Pendekatan Kualitatif, Kuantitatif dan Mixed. Pustaka Pelajar.

Dewi, L. (2017). Designing Online Learning In Higher Education Institution: Case Study In Curriculum And Instruction Course At Indonesia University Of Education Bandung. 16.

Elliott, J. (2016). Significant themes in developing the theory and practice of lesson study. International Journal for Lesson and Learning Studies, 5(4), 274-280.

Fraenkel, J. R., Wallen, N. E., \& Hyun, H. H. (2011). How to design and evaluate research in education. McGraw-Hill Humanities/Social Sciences/Languages.

Frydenberg, M., \& Andone, D. (2011). Learning for 21 st Century Skills.

Hajar, M.U., \& Hendayana, S. (2018). Lesson Study As A Meands of Transforming Classroom Discourse and Student Cognitive Engagement in Science Classroom. Journal of Physics: Confreence Series. https://doi.org/http://dx.doi.org/10.1088/1742- 6596/1157/2/022050.

Hajar, M.U. (2019). Analisis pola dialog pembelajaran IPA menggunakan TBLA (Transcript Based Lesson Analysis) di salah satu SMP Kota Bandung. Universitas Pendidikan Indonesia respiratory.upi.edu perpustakaan.upi.edu.

Hendayana, S. et. a. (2006). Lesson Study. Pengalaman IMSTEP-JICA.

Hidayat, A. Hendayana, S. (2020). Panduan Sesi Simulasi, Reflektif-Penggerak: Mengupas Learning Patterns? Workshop Internasional Pendidik Penggerak Pembelajaran Reflektif. Jumat 21 Agustus 2020.

Hidayat, H. (2020). Praktek Transcript Based Lesson Analysis (TBLA); Workshop Internasional Pendidik Penggerak Pembelajaran Reflektif. Jumat 28 Agustus 2020.

Kemendikbud. (2019). Workshop Lesson Study.

Marten, D \& Clerc-Georgy, A. (2015). Use of theoritical concept in lesson study: an example from teacheer training. International Journal for Lesson and Learning Studies, 4(3), 261-273. https://doi.org/http://dx.doi.org/10.1108/IJLLS-10-2014-0039

Mutiani. Warmansyah, M. Abbas Syaharuddin. Susanto, H. (2020). Membangun komunitas belajar melalui lesson study model transcript based learning 
Susetyorini et.al - JINoP (Jurnal Inovasi Pembelajaran) 7(2)(2021)pp.141-152

analysis (TBLA) dalam Pembelajaran Sejarah. HISTORIA: Jurnal Pendidik Dan Peneliti Sejarah, 3(2), 123-134. https://doi.org/https://doi.org/10.17509/historia.v3i2

Pangestika, I. W., Ramli, M., Nurmiyati, N., \& Sapartiwi, S. (2017). Hasil belajar biologi siswa kelas XI MIPA melalui penerapan dialog Socrates. Proceeding Biology Education Conference Vol. 14, 305-310.

Rahayu, D. S. (2019). Analisis Pola Konstruksi Pengetahuan Siswa dalam Pembelajaran Ipa Pada Materi Gelombang Menggunakan Tbla (Transcript Based Lesson Analysis) di Salah Satu SMP Kota Bandung. UPI Bandung.

Sarkar Arani, M. R. (2017). Raising the quality of teaching through Kyouzai Kenkyuu-the study of teaching materials. International Journal for Lesson and Learning Studies, 6(1), 10-26.

Sato. (2012). Mereformasi Sekolah: Konsep dan Praktek Komunitas Belajar. International Development Center of Japan. Inc.

Sato. (2014). Dialog Kolaboratif di Sekolah Menengah Pertama Praktek "Learning Community. JICA (Japan International Cooperation Agency).

Setiawan, A. Mujianto, G. Asihono, D. (2020). Meningkatkan keaktifan siswa kelas VII dalam mata pelajaran bahasa Indonesia dengan menggunakan pendekatan saintifik dalam kegiatan lesson study. JINoP, 6(2), 164-180.

Sugiyono, P. (2015). Metode penelitian kombinasi (mixed methods). Alfabeta.

Sukardi. (2007). Metodologi Penelitian Pendidikan: Kompetensi dan Praktisnya. Bumi Aksara.

Supriatna, A. (2018). Kegiatan Lesson Study sebagai Upaya Guru untuk Menemukan Pembelajaran yang Memenuhi Keperluan Anak Hidup pada Zamannya (Era Revolusi Industri 4.0). Seminar Nasional Edusainstek ISBN FMIPA UNIMUS, 978-602-56, 1-5.

Susetyarini, E; Rofieq, A.N, Latifa, R. (2018). Implementasi Lesson study for Learning community Guru-Guru SMPM 8 Kota Batu. Laporan PPMI. DPPM. $U M M$.

Susetyarini, E; Rofieq, A.N, Latifa, R. (2019). Implementasi Lesson study for Learning community Guru-Guru SMPM 8 Kota Batu Laporan PPMI DPPM $U M M$.

Susilo, H, Chotimah, H, Ridwan J, Jumiati, Yuyun D.S, dan S. (2009). Lesson Study Berbasis Sekolah. Bayu Media Publisihing.

Triani, L., Wahyuni, S., Purwanti, E., Hudha, A., Fatmawati, D., \& Husamah, H. (2018). Pembelajaran I-CARE berbantuan praktikum: Peningkatan problemsolving skills dan hasil belajar siswa pada materi jaringan hewan. Jurnal Inovasi Pendidikan IPA, 4(2), 158-168.

Ulfah, M. (2012). Optimalisasi hasil belajar IPA tentang sistem gerak pada manusia melalui metode diskusi dengan tehnik pembelajaran tutor sebaya. Dinamika, 3(1), 19-24.

Wahyuni, S; Susetyarini, R.E, Latifa, R. (2015). Peningkatan Kemampuan Berpikir Kritis Mahasiswa Pendidikan Biologi UMM Melalui Lesson Study Jurnal Inovasi Pembelajaran. Jurnal INovasi Pembelajaran (JINoP), 1(2), 187-200.

Wahyuni, S. Permana, T. . (2019). Project-Based Learning: A Hands-On Activity to Improve Students' Scientific Writing Skills through Lesson Study in Microtechnique Course. Journal of Biology Education, 8(3), 340-347.

Wahyuni, S. Purwanti, E. Hadi, S. Fatmawati, D. (2019). Anatomi Fisiologi Tumbuhan. Universitas Muhammadiyah Malang UMM-Press. 